\title{
Penetrating the Mist of Horror in Post-9/11 Era: A Study of Narrative Violence in Tree of Smoke (2007)
}

\author{
Shao Bingqing and Liu Xiao
}

\begin{abstract}
Continuing trauma writing and anti-war topics of previous Vietnam War literature, Tree of Smoke (2007), the winner of 2007 American National Book Award, is affected by the trend of violence presentation in post-9/11 era and keeps a watchful eye on militarism of U.S. empire in the fall Saigon, a place surrounded by horror. The novel differs itself from traditional Vietnam War novels in that it addresses more about violence outside the battleground in forms of language, religion, even consumer goods, rather than massacre, slaughter and killing on the battleground, underlying a more subtle form of violence manipulated by U.S. Empire. This thesis is going to employ $\check{Z}$ iž ek's violence theory and dedicated to revealing the mechanism of how imperial language motivates the expansionist doctrine to justify imperial activities, unmasking the logic of exceptionalism through detailed analyses of symbolic violence, employing various narrative techniques.
\end{abstract}

Index Terms-Symbolic violence, tree of smoke, violence narrative, exceptionalism, imperialism.

\section{INTRODUCTION}

The tradition of imperialism has long existed in American history since "May Flower" anchored at Plymouth. It manifested itself in the form of exceptionalism as first Puritans moved westward from Virginia. Within the U.S. empire, the nation has developed around the exceptionalist ethos in a way that is maybe exaggerated, or even increasingly aggressive.

Vietnam War, as a significant war that triggered by swelled national psyche and driven by American "errand in the wilderness" to promote democracy against any totalitarian and communist party across boundaries during the cold war, has inflicted profound impacts on American society, the failure of which left trauma on an entire generation and haunted Americans for decades until the victory of the Gulf War.

Ironically, tens years after George W. Bush announced in a euphoric victory statement at the end of the Gulf War, "we've kicked the Vietnam syndrome once and for all"1, whatever memory of the Vietnam War remained seemed to be decisively interred with Al Qaeda's attacks on the Pentagon. In the wake of $9 / 11$, exceptionalism was recuperated to mobilize the "war on terror" in the name of Pax Americana. The invention of the nouns such as "failure country", "rogue state" and "axis of evil" 2 even push American ideal of

Manuscript received May15, 2015; revised September 19, 2015.

The authors are with National University of Defense Technology, China (e-mail: shaobingqing@vip.sina.com, liuxiao3333@163.com).

${ }^{1}$ George Bush, to a group of legislators, reported in Newsweek, 117, March 11, 1991.

${ }^{2}$ U.S. President George W. Bush used the term Axis of evil in his State of the Union Address on January 29, 2002, and often repeated it throughout his presidency, to describe governments that he accused of helping terrorism and freedom further to every corner of the world, while at the same time help to build "U.S. new empire" into the mode of Puritan morality ${ }^{3}$.

Setting against the background, a literary form called "post-9/11 literature" emerged in the era, aiming at reflecting on the history and concerning for human beings. Contemporary writers endeavor to challenge the official discourses. They try to cast doubt over the justification of Iraq War, and topple town the biased narratives as well as glorious myths created by the manipulative media.

As one of the prevailing post-9/11 fictions, Tree of Smoke (2007), written by American writer Denis Johnson, announced its uniqueness and went against the current. Compared with other writers who largely concentrated on the heated topic of 9/11, Johnson chose to switch public's attention to the Vietnam War, peeping through the war in Saigon through acute post-9/11 lens and reconstructing the singular Vietnam history.

\section{Previous Researches AND TheOREtical Bases}

The tome is no doubt a masterpiece combined of "big historical theme, semi-mythical cultural institution (military intelligence), long time span (1963-70), with a coda set in 1983 ) and unreasonable length (614 pages)." [1] The full and bloody narrative of the war in the fiction arouses not only people's regret for Vietnam War, but also rethinking of intense Iraq situations today. It is clearly up to something bigger than a mere memorial of Vietnam War ${ }^{4}$. As Garth Risk Hallberg (2007) points out, "Tree of Smoke (2007) is an attempt to write about the present through the prism of the past" [2].

Media response towards the book is quite positive, so are the literary critics. NY Times Book Review, Washington Post and Seattletimes all set a high value on the book. More detailed than the compliments on media, existing criticism from foreign critics and academic scholars are concerned with narrative techniques, theme exploration, creation

seeking weapons of mass destruction, for instance, Iran, Iraq and North Korea, which simplifies the fact and invites wide criticism.

${ }^{3}$ In 1630, John Winthrop' s sentiment, “wee shall be as a Citty upon a Hill” (Madsen, Deborah L. American Exceptionalism. Jackson: University Press of Mississippi, 1998.), became the foundation of puritan sermons. Since then, puritans regard America as the "chosen nation" by the god, and they are bestowed with the mission to save the world.

'According to Johnson' s manuscripts, it cost him 14 years to finish the book. Back in 1980s, Johnson began to develop the idea of the novel and started shuttling between America and Southeast Asia to interview veterans and witnesses who had survived the war. Having finished the primary accumulation of first-hand materials, Johnson started puttering and tinkering with ideas, and designed the framework of the novel in 2003, the year when Iraq War broke out. The main body was completed during 2004 to 2006 . By 2007 , the work is presented to the public. From tracks above, it can be referred that the novel is set in $9 / 11$ background. 
background and so on.

Among the many themes discussed, religion is often discussed. "Tree of Smoke" is a portent day when "the sun shall be turned to darkness, and the moon to blood, before the great and terrible day of the Lord comes." [3] Thien underscores that the image of the Tree of Smoke (2007) manages to convey a sense of gorgeous and horror, with revelation of theology. It signifies the lose of faith and belief in God, as well as disaster brought by war. If other critics accuse war is hell, then Steve Poole (2007) sharply concludes, "war is absolute freedom. In it, men create their own hell." Poole carefully analyzes the "densely, thrilling populated" [4] characters, and revolutionizes stereotyped views towards violence, which is triggered by war instead of being imposed by war. The review somehow guides readers to go a step further to focus on the wire-fullers of the war behind the curtains.

Besides all the narrative analysis and theme exploration, the creation background of Tree of Smoke is brought up over the time as a vital question. Yu Jianhua (2008) traces the war novels that win Pulitzer Prize and National Book Award since Iraq War [5], which consists of March (2005), Europe Central (2005), the Great Fire (2003) and etc. He concludes that it is of no coincidence that war writings repeatedly win the awards since Iraq War, partly because the large cost and sacrifice of young soldiers infuriated the public, making Iraq War an unavoidable topic for literary discussion. As media invades in people's lives and brings about bloody facts, fear of terror, as well as the tremendous physical and psychological pressure suffered by the American soldiers, writers who are under great anxiety intend to find a way out of today's dilemma through past lessons. Except for the chronicles of war novels, Zhao Liping (2008) has discovered an interesting phenomenon that both of the works winning National Book Award are related to CIA [6]. The other winner of non-fiction novel is Legacy of Ashes: The History of the C.I.A. (2007). By exposing CIA's terrible record and overthrow its formidable reputation, both novels hand over us an overview of U.S. intelligence agency and enlighten us to rethink the embedded imperial logic behind corrupted national policy. The better part lies in that based on the 9/11 reality, Tree of Smoke extends beyond Vietnam and stretches to World War $\Pi$, even referring to colonial period back in 19th century when European imperialism reached its peak. At the same time, the geological background cuts across Vietnam, Philippines, Japan and America. After discussion about the creation background, it should be reflected that what the similar backgrounds of the Vietnam War and Iraq War are, why the U.S. recommits the same error and how to avoid the tragedy.

As a key element in post-9/11 literature, narrative associated with violence not only focuses on presentation of the horrible event, but also pays close attention to a broader historical background such as Afghanistan War, Iraq War, genocide and other violent incidents. Continuing trauma writing and anti-war topics of previous Vietnam literature, Tree of Smoke (2007) is also affected by the trend of violence in post-9/11 era. The novel differs itself from traditional Vietnam literature in that, there's only one of the eight chapters that directly describes fierce battle scenes. Rather, it concerns more about subtle violence outside the battleground in forms of maltreatment, rape and assassination, which fills the novel with depressive atmosphere. The unique writing style inspires retrospection of Žižek's violence theory.

Žižek's Violence: Six Sideways Reflections (2008) mainly refines the notion of violence and divides violence into three categories-subjective violence, objective violence and systemic violence [7]. In his view, violence extends far beyond the physical violence that presented to us everyday from the world. There exist more subtle forms of violence, for example, language. The theory tries to subvert the ways free-market capitalism indoctrinates people to recognize violence, and pierces through "the safe world" media build for us. Žižek's theory shed some light on the reconsideration of Johnson's novel. His acute criticism on capitalism and imperialism lays a solid foundation for the essay.

On the basis of narrative theory, this essay adopts Žižek's division of violence and create violence narrative--with regard to the violent world created by media in the $21 \mathrm{st}$ century, violence narrative employs narrative techniques to analyze the violence theme presented by physical violence, symbolic violence (through images, language and so on) through text, which is literally a form of discursive violence itself, so as to expose systemic violence of imperialism.

This essay is going to discuss three aspects of symbolic violence contained in the novel, which are religion, icon and language.

\section{Penetrating Divine Violence through Variable FOCALIZATION}

William V. Spanos succinctly discusses the ontology of American national identity in his book American Exceptionalism in the Age of Globalization (2008). He thinks the origin of exceptionalism lies in the American Puritans' belief that was

"divinely or transcendentally ordained and which became hegemonic in the course of American history with its secularization as Manifest Destiny in the middle of the nineteenth century and as the end of history and the advent of the New World Order at the end of the twentieth century" [8].

United States' devastation of Vietnam exemplifies the latent violence beneath the "benign logic" of exceptionalism. Under such logic, the catastrophic wars, Vietnam War and 9/11, are usually regarded as the outrage of the God to punish guilty human beings, which is referred by Žižek as "divine violence", a kind of symbolic violence. This chapter endeavors to deconstruct divine violence and probe into the fallacy behind it, trying to topple down the Puritan belief as a manifestation of superior homogeneous culture by going through variable focalization of Buddhism and Confucianism in the novel.

Tree of Smoke (2007) is largely a religious book, concerning that the title of the book is drawn from the Bible--"cloudy pillar", a sign of the Second Coming ${ }^{5}$. It indicates that all the sufferings, earthquakes, floods, famine and wars in the mundane world, are the apocalypse of the end of the world. When the day comes, those chosen by the God will survive, those doesn't believe the power of God's mercy,

\footnotetext{
${ }^{5}$ The Second Coming refers to the return of Jesus Christ, ushering in the ultimate rule of God and His judgment on humankind.
} 
shall feel the fire of his indignation.

As is shown in the episode of Kathy reading a book about John Calvin ${ }^{6}$, and his doctrine of predestination:

"Certain persons positively and absolutely chosen to salvation, others as absolutely appointed to destruction."

The chosen theory alienates Americans who are the "chosen people" carried with "errand in the wilderness" and "Vietnamese Other" who live under undemocratic political system and need salvation. It masks U.S. empire's military intervention over the national boundary as a justified activity to liberate people in inferior third world countries.

"Although, therefore, those things which are evil, in so far as they are evil, are not good, yet it is good that there should be evil things."

"And if God foreknew that they would be evil, evil they will be, in whatever goodness they may now appear to shine" [9].

The logic of predestination and violence lurking under the divine violence is indoctrinating Christians to believe that, despite Vietnamese' simplicity and harmlessness, this enemy is still evil. Judgment should fall upon them. In this way, it may alleviate the guilt of American soldiers, thus successfully divides the world into "us" and "them", the same logic U.S. employs to demonize Islamist.

Besides Christian, Denis Johnson embeds Buddhism and Confucianism in the novel as religions originated in Asia and embody Asian philosophy. The Asian religion functions as a rival focalization against Western religions.

In Buddhism, "life is suffering. Suffering comes from grasping. Grasping can be relinquished...suffering comes from clinging to things that won't stay" (p. 394).

"The Confucian tells us how to behave when fate grants us peace and order. The Buddhist trains us to accept our fate even when it brings us blood and chaos" (p. 23).

"We have the Confucian mode for times of stability-for wisdom, social conduct, and so on. We have the Buddhist mode for times of tragedy and war-for acceptance of the facts, and for keeping the mind single" (pp. 391-392).

The alternation of the perception center reflect a thematic confrontation between the Asian and Western value systems. View here combines ideology and frame of religion. The ethos of Buddhism and Confucianism differ from Christian and Catholicism in that they encourage peace and harmony, and teach people to face tragedy and war--a kind of non-violent strategy cheering people up in times of invasion and natural disaster. For Buddhists, tolerance is a merit and relinquishment is wisdom. Focusing on the mindset of oneself is the primary concern for them, rather than the secularization and political-involving creeds Puritans hold.

Ironically, puritans seem to have forgotten that they were exiled due to the tyranny of religious persecution in the Thirty Years War between Catholicism and Protestants. After then, liberalism emerged in the American land on the other side of the Atlantic Ocean, on which Christianity thrives. They've suffered from disrespect towards other religions and cultures themselves and wished to build a "God's realm" where exists no more prejudice and oppression, but now

\footnotetext{
${ }^{6}$ John Calvin develops Calvinism (also called the Reformed tradition, Reformed Christianity or the Reformed faith), which is a major branch of Protestantism that follows the theological tradition and forms of Christian practice of John Calvin and other Reformation-era theologians.
}

that's exactly the same tyranny they are imposing on the "undemocratic countries" according to their standards.

"One God, but different administration" (p. 76). The notion might best illustrate the relationship between different branches of religions, and minimize the divergence among each of them. People who share the same devout attitude towards the God should co-exist with equality and respect.

\section{RECOGNIZING MANUFACTURED CONSENSUS IN ICONIC SYMBOLISM}

An icon originally refers to "a religious painting in the tradition of Eastern Christianity"7. Almost everything within the image has a symbolic aspect, including the characters, colors, letters and etc. Later on, more recognized symbols derive from icon, like culture icon, pop icon and secular icon. An imagery icon works as an ideal medium of symbolic violence in that it transmits ideas through more visual and direct pictures or notions that is simple, iconic, easy to remember and easy to promote.

On the course of imperialism, U.S. not only dedicates to military expansion, but also actively promotes culture domination. In the novel, U.S. managed to build national identity through establishing a war hero and leader idols domestically, at the same time promoted capitalist culture by disseminating capitalist icons all over the world, with the intention of manufacturing consensus and infusing exceptionalism both at home and abroad.

People who have read Heart of Darkness (1899) or ever watched Apocalypse Now (1979) must find resemblances between Colonel Kurtz, the most iconic rogue soldier in the imaginative mythology of the Vietnam War, and Colonel Sands, the autocratic legendary war hero who despises rules and disciplines in Tree of Smoke (2007). By setting the character in the novel, the author pays homage to Joseph Conrad and Francis Coppola, who created peaks in war novels and movies. Tree of Smoke (2007) inherits their operatic surrealist style and provokes significant reflection towards the theme of war and imperialism.

As an icon on the battlefield, Colonel is worshiped as "the King of Cao Phuc", a "warrior", "a genuine war hero" and a "myth" himself given his meritorious military service. He once served in the Flying Tigers in Burma, survived the Japanese POW camp, carried out antiguerrilla operations in Vietnam with Edward Lansdale and faced enemies on many Asian fronts. In Vietnam, he performs psychological operation all on his personal authority due to admiration of subordinates. Almost every soldier has heard of him, and he's already become a legend in the U.S. Army.

An icon usually inspires people, motivates people, and invoking wide imitation. Colonel is an icon that has inflicted his personal impacts on numerous soldiers on the battleground, pulling them together and leading them through lost and confusion by his strong belief and tough action. He portrays the God in Southeast Asia battleground, the evidence of which could be traced in the symbolic prophecy and characters. Judas ${ }^{8}$ first appearance in priest Carignan's$$
\text { Retrieved May 29th, }
$$

http://en.wikipedia.org/wiki/Icon_(disambiguation) 2015 from

${ }^{8}$ According to the New Testament, Judas Iscariot was, one of the twelve original disciples of Jesus Christ. He is known for the kiss and betrayal of
} 
confession of betrayal enlightens readers to notice the symmetry of characters, setting a allegorical tone throughout the novel. After Colonel is betrayed, the allegory becomes more obvious that Colonel portrays the role of God who rules over all in Vietnam with a lot of faithful followers. Moreover, Colonel's death after inhuman torture is compared to the crucifixion of Jesus Christ, and his funeral is covered with mysterious color and compared to resurrection of Jesus in that "his coffin heaved to the surface, and Colonel Sands came back from the underworld", finding "a naked young Colonel Francis unblemished, unmolested.”(pp. 450)

The secularized God, the performer of justice, idolized by U.S. soldiers who share his belief of militarism, however, is a frantic extremist. He views "violence as inevitably human and warriors as peculiarly blessed" (p. 448) He "believes in himself", "learns on the run" and "fights without thought of surrender" (p. 449). Faced with unorthodox adversaries who hold different ideology, "believe in central command" and "in the unthinkable sacrifice", Colonel falls into typical cold-war paranoia--communists will become uncontainable unless we "hang on until Communism collapses under the weight of its own economic silliness" before "there's somebody else going Red" (p. 57). The urgent awareness of the need for a perpetual frontier between wilderness and civilization always threatens the "fulfillment of the errand" is then rejuvenated, which, to be fair, rallies nation's support and unites them together to confront the same enemy.

For U.S. government, Colonel is a perfect war machine for his devotion to the war, enjoyment in the killing, and most of all, hatred against communism. His sovereignty and history can be packaged into a national icon that functions to manufacture consensus among the Americans, build American national identity, and promote hostility towards other ideologies so as to win the war.

Unexpectedly, the ideal patriotic dough boy symbolizing American supreme glory in WWII and American hegemony in the 20th century is killed, the order of which is taken from CIA. The author sets the death of Colonel with an attempt to disclose the self-contradictory logic of American imperialist activities and predicts doomed future of militarism.

With regard to the forms violence takes, William Spanos also points out, the logic of "a diversity of immigrants" who are based on "the homogeneous culture" produces "hegemony of transnational capitalism". In the novel, visual icon is everywhere, ranging from Mercedes, Coke-cola, Levi's, Rayban, Union cigarettes, Dixieland recordings and so on, all of which are symbols of American pop culture from consumer goods to music.

As the perfect epitomized icon of post WWII consumer culture, coca-cola not only crosses but erases the international boundaries, demonstrating a perfect example for the global village of transnational capitalism. Coke is a brand that attracts young people to chase after, and a brand that invokes people's desire to consume not merely as a soft drink, but as a fashionable icon. Thomas P. Waldemer (2008) once states that "a logical implication of this triumphant 'coca-colonialization' might be an inexorable trend towards global cultural uniformity" [10] Every time people in other

Jesus to the Sanhedrin for thirty silver coins. His name is often invoked to accuse someone of betrayal. Retrieved May 29th, 2015 from http://en.wikipedia.org/wiki/Judas_Iscariot. corners of the world consume coke, they are consuming the symbolic product of American culture. Capitalist life style prevails in the third world and invades in every corner as an invisible force disseminating capitalist ideology and belief of materialism and life of pleasure. In a dialogue with Kathy, Skip puts it:

"These folks around here will never have much better than what they've got. But their children might. Free enterprise means innovation, education, prosperity, all the corny stuff. And free enterprise is bound to spread, that's its nature. Their great-grandkids will have it better than we do in the States." (p. 94)

The conversation largely conforms to the actual mindset of Americans--people in communist countries are undergoing extreme poverty and backwardness, while Americans are proud to invent the multinational enterprises that benefits the rest of the world and they are confident their culture is going to influence the next generation and better the future of undeveloped countries. It urges people to believe communist country would finally be integrated into a borderless world dominated by transnational corporations. By inserting the icons, the author intends to present superiority of American citizens, the tools of exceptionalism and ways of capitalist expansion.

\section{DEEPENING EXCEPTIONALISM THROUGH DiscourSE MANIPULATION}

The implied author doesn't speak, but he manipulates. In Tree of Smoke (2007), Denis Johnson shows his attitude towards exceptionalism by juxtaposition of two religions and icon fabrication. Moreover, in the process of composition, he creates various characters and designs their dialogues, as well as depicts certain circumstances to subtly express his opposition to exceptionalism. Since another crucial elements of symbolic violence is language, which can also be inferred as discursive violence, the power to narrate, or eliminate other narratives, is very important in forming readers' views and transmitting author's subconscious attitude - in Edward Said's words, "textual attitude". The manipulation of the discourses mainly focuses on the built of the image of J. F. Kennedy, the discussions on Vietcong.

The novel starts with, "Last night at 3:00 a.m. President Kennedy had been killed." (p. 3) J. F. Kennedy ${ }^{9}$ is also an iconic figure like Colonel in the novel, and in real American history. During his presidency, Kennedy won wide support domestically and ranks highly in public opinion ratings of U.S. presidents in American history. But academics hold quite different opinions towards him.

In the first chapter, two plots are set interwoven with each other - Kennedy's death and Bill's killing of a monkey, both symbolizing the lose of innocence. Moreover, in later parts,

\footnotetext{
${ }^{9}$ John Fitzgerald Kennedy was an American politician who served as the 35th President of the United States from January 1961 until his assassination in November 1963. Notable events that occurred during his presidency included the Bay of Pigs Invasion, the Cuban Missile Crisis, the Nuclear Test Ban Treaty, Police Week, the establishment of the Peace Corps, the Space Race-by initiating Project Apollo (which later culminated in the moon landings), the building of the Berlin Wall, the African-American Civil Rights Movement, and the increased U.S. involvement in the Vietnam War. $\begin{array}{llll}\text { Retrieved } & \text { May } & \text { 30th,2015 } & \text { from }\end{array}$ http://en.wikipedia.org/wiki/John_F__Kennedy.
} 
time is longer marked by a certain number, but by the year of Kennedy's death, emphasizing the traumatic shock and grief of Americans, so it does to the author.

"It was 1967, more than three years after the murder of John F. Kennedy" (pp. 8).

"The afternoon of that November day in 1963, the day after John F. Kennedy's assassination" (pp. 12).

In Colonel's eyes, John F. Kennedy was "a beautiful man" and "one of the good heroes". He also calls himself a "Kennedy man", inheriting his liberty, patriotism and justice. After Kennedy died, a film was shot to memorize him--Years of Lightning, Day of Thunder, "recounting the brief, tragic, heroic span of President John F. Kennedy's life." In the film, "the view closed in on the eternal flame marking John F. Kennedy's grave, a squat torch which the Americans intended to keep alight forever" (p. 24) The congress even authorized to issue "John F. Kennedy half dollar" intended as a memorial to the assassinated President just over a month after his death. The coin circulated widely among American citizens.

Before the release of Kennedy's scandals, he portrays a perfect public figure and responsible politician who devoted limited number of military force in Vietnam and was reluctant to order a full-scale deployment of troops. He supported South Vietnam regime politically, economically, and militarily, and attached great importance to intelligence and psychological operations in Vietnam. When the situation worsened, he was moving in a less hawkish direction and decided to withdraw, which was the reason many left-winged politicians claimed that they would not be defeated in Vietnam if Kennedy was not assassined. Apparently, Johnson supports the opinion in that Kennedy's image is positive throughout the novel despite his mistake at the Bay of Pigs. However, Kennedy's stance on containment of communism and exceptionalist capitalist ideology is supported by American soldiers in the novel, and is never challenged, not even criticized by characters of native Vietnamese. In fact, native Vietnamese are all designed wordless towards the ideology issue. The only voice is a double agent Trung from Vietcong, who acidly satirizes Vietcong. Apparently, Johnson supports the opinion in that Kennedy's image is positive throughout the novel despite his mistake at the Bay of Pigs. However, Kennedy's stance on containment of communism and exceptionalist capitalist ideology is supported by American soldiers in the novel, and is never challenged, not even criticized by characters of native Vietnamese. In fact, native Vietnamese are all designed wordless towards the ideology issue. The only voice is a double agent Trung from Vietcong, who acidly satirizes Vietcong.

Colonel is the typical character who advocates for American democracy and hates communists. He curses Vietcong leader, and regards them as inferior species like rats "living in holes in the ground." He even demonizes them like "they're eating their children in the name of victory. That's what they eat for lunch." (p. 342) All of the hatred partly derives from segregation, partly from fear, reflecting most of American soldiers' Orientalism.

In Trung's view, the Vietcong are ignorant and cold-blooded. They dispose their comrade's body like a lifeless thing without respect, and their addresses are ridiculous and mechanical like "nothing but crap". They live on the kolkhoz farm without freedom like a "monstrosity". All the time, Trung cursed himself for participating Vietcong.

"I remembered the red earth of Ben Tre, not the yellow earth of the North. I remembered the warm southern days, not the chilly northern nights. I remembered the happiness of my village and not the rivalry and thieving of the kolkhoz...You can't throw people together and forbid them to leave and tell them they're a commune united by doctrine."(pp. 393)

The comparison between North and South Vietnam clearly demonstrates the author's favor of political environment in South Vietnam, which is supported by the U.S., as well as his oppose to North Vietnam's totalitarianism and dictatorship because of his exceptionalist perspective.

There are no rival speeches nor comments arguing for the communist side. The unbalanced presentation of the Vietcong reflects author's ocularcentrism haunted by fixed imperialist vision, which has fundamentally deepen exceptionalism in domestic spheres.

\section{CONCLUSION}

The essay mainly explores presentation of symbolic violence with regard to exceptionalism theme in post-9/11 fiction Tree of Smoke (2007) based on Žižek's violence theory. It consists of three parts, the angle of which ranges from religion to discourse. The first part traces the origin of exceptionalism which is deeply rooted in Puritan ethos, penetrates the fallacy of "chosen theory" of Calvinism that justifies imperialist activities, and discloses divine violence latent in Christianity through switch of focalization to Buddhism and comparison between the creeds of the two religions. Part two focuses on the means of propagandizing exceptionalism, which is building national icons that's motivating and inspiring, embodying capitalist values and tough foreign policies. These icons carry American culture to other parts of the world by transnational corporations, and cultivate American capitalist life style in target countries, with an attempt to alter the future of the next generation. The third part discusses the complexity of author's attitudes towards exceptionalism in presenting the novel. This part unveils the author's control over discourse, which actively promotes American hegemony and cultivates hatred towards communism through subtle manipulation of the characters and their speech presentation of Vietcong.

To conclude, the author's attitude towards exceptionalism is complicated and contradictory. He tries to reveal and opposes exceptionalism, but subconsciously can't get rid of Western thinking and imperial vision that's deeply rooted in his American identity. The reason of self-contradictory presentation of the novel is owing to the author's multi-identities as a righteous writer, a war witness and a native American. As a righteous writer who concerns about the current political issues and the future of the world, Johnson condemns war and American imperialist behaviors. As a war witness and journalist, he looks into the battleground and catches the most detailed expression of American exceptionalism, with the attempt to protect innocent human beings from flames of war and call for peace. The day Tree of Smoke (2007) won National Book Award, he 
was still in Iraq. As an American, he is born during the Cold War, and raised in a community that's hostile to communists and paranoid about the spread of the "Red", most of all, flooded with all kinds of anti-communism cultural products like movies and novels. Even if he has traveled to Philippines, Vietnam and other countries, his endowed Western perspective of Vietnam and capitalist ideology of politics can't be easily changed. On the other hand, when exceptionalism is closely paid attention to and brought up again and again, it is in fact another kind of propaganda, similar to the fact that constant exposure to violence would more likely trigger violent behaviors in societies. Over-emphasis on exceptionalism may invoke more blind patriotism and proud of national identity.

The essay manages to disclose the religious origin of exceptionalism, the method of its dissemination, as well as reflection of its status quo in the context of post-9/11 era, warning us not to tread on the same historical path again. Due to multiple elements in the novel, it requires the researcher to conduct research under interdisciplinary perspectives. The essay combines culture studies, theology studies, military studies and other subjects, trying to render an overall understanding of the novel. By assembling different perspectives from various disciplines, the essay highlights the significance of narrative and its function in aesthetics and politics in post-9/11 era.

\section{ACKNOWLEDGMENT}

Shao Bingqing is grateful to Professor Liu Xiao, for her support on my essay. She gave me bunches of advice and helped me conquer many difficulties in both my study and my life. I offer my sincere appreciation and gratitude to Professor Liu's patient advice, warm help and edits of the documents. She has planted in me the seeds of literature and instilled in me appreciation for post-9/11 works, as well as helped me to find my path through Vietnam War literature and through this life I've been granted. I owe a great deal to her for the accomplishment of this project.

\section{REFERENCES}

[1] J. Lewis, "The revelator," New York Times Book Review, vol. 7, no. 1, 2007.

[2] G. R. Hallberg. (2007). Message from a dead man: A review of denis johnson's tree of smoke. The Millions. [Online]. Available: http://www.themillions.com/2007/10/message-from-dead-man-review -of-denis.html

[3] M. Thien. (2008). Tree of smoke. Waterbridge Review. [Online]. Available: http://www.waterbridgereview.org/092008/rvw_tree.php
[4] S. Poole, "Realitybites," New Statesman, vol. 4780, no. 136, pp. 52-53, 2007.

[5] J. H. Yu, "Bring up the topic of war: The old shadows and anxiety today," Anthology on British and American Literature, vol. 2, pp. 8-13, 2008.

[6] L. P. Zhao, "Smoke of war, tree of soul - the work winning 2007 American national book award and its author," Yilin Press, vol. 2, pp. 180-182, 2008.

[7] S. Žižek, Violence: Six Sideways Reflections, Picador: New York, p. 11, 2008.

[8] W. V. Spanos, "American exceptionalism in the age of globalization," State University of New York, p. 188, 2008.

[9] D. Johnson, Tree of Smoke, Farrar, Straus and Giroux: New York, pp. $83-85,2007$.

[10] T. P. Waldemer, "Imperfect harmony: Coca-Cola and the cannibal metaphor in beba coca cola, Sangue de coca-cola, and a hora da estrela," Hispanofila, issue 153, p. 97, May 2008.

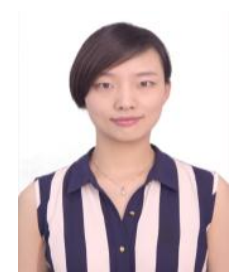

Shao Bingqing was born in Ningbo, Zhejiang Province, China on November $1^{\text {st }}, 1990$.

She got her BA degree in foreign language and literature in National University of Defense Technology in 2013. She has been a master student in American war literature in NUDT since 2013.

Her major field is Post-9/11 literature and American war literature.

Her publications include: "Looking into the building of China's image through A Bite of China," International Conference on Cross-cultural Communication and National Image Construction, 2013; "The Vietnam war in the new century: The evolution of apocalypse now redux (2001) in narrative perspective," Journal of Literature and Art Studies, pp. 100-106, 2015.

Ms. Shao's current and previous research interests are narrative criticism, Vietnam war literature and post-9/11 literature.

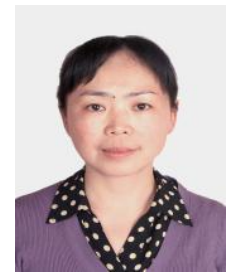

Liu Xiao was born in Changsha, Hunan province, China on July $16^{\text {th }}, 1968$. She got her MA degree in English literature from Hunan Normal University in 1994. She got her Ph.D. degree in comparative literature from Beijing Language and Culture University in 2008. Her major fields are narrative criticism and American war literature.

She has been working as a teaching staff member in English Department of National University of Defense Technology since 1995. Currently she is the director of Institute of Language and Culture in the School of Humanities and Social Sciences in National University of Defense Technology. Her recent publications include: Trauma and Narrative, A study of Tim O'Brien's Works after 1990, Beijing, China: Social Sciences Press House, 2013; "Writing of the Vietnam war after 9/11: Analysis of July," Contemporary Foreign Literature, 2013; "Reinterpretation of Tomcat in Love," Foreign Literature, 2012. Her previous research interests include stylistics, narrative criticism and American literature of the Vietnam war. Currently, she is very interested in the cold war literature and culture.

Professor Liu Xiao is a member of the Association of China's Comparative Literature and China's Narrative Theory. 